\title{
THE INFLUENCE OF WORK-FAMILY CONFLICT ON EMPLOYEE SILENCE AMONG EMPLOYEES OF SECONDARY EDUCATION AL- HIDAYAH MEDAN INDONESIA
}

\author{
${ }^{1 *}$ Nurul Atikah, ${ }^{2}$ Dhian Maulidya, ${ }^{3}$ Suchroni Panjaitan, and ${ }^{4}$ Khairunnisa \\ 1,2,3,4English Applied Linguistics Study Program, Post Graduate Program \\ State University of Medan, North Sumatera, Indonesia \\ *Corresponding author: nurulatikah369@gmail.com
}

\begin{abstract}
Employee silence is used by employee in Indonesia as the way to solve the problem. Being silent, the employee tends to withhold the information that might be necessary for the organization. The silent employee affects the work-family conflict. This research is aimed to investigate the influence of work-family conflict on employee silence of SMP Al-Hidayah Medan. Quantitative research methodology (Ary et.all, 2002) is used in conducting and analyzing the data. The data were collected by applying relevant questionnaires. There are 10 respondents in this study, consisting of 5 females (50\%) and 5 males (50\%). SPSS Statistics software is used in analyzing the data. The finding reveals that Work-family conflict has a significant effect on employee silence. The result also parades that Work-family conflict has contributed $84.5 \%$ to employee silence and $15.5 \%$ to other factors outside the Work-family conflict described in this study. It indicates that employee silence does not only occur cause of Work-family conflict but also by other factors. It could be the further research about the causes of employee silence.
\end{abstract}

Keywords: silence, employee silence, work-family conflict

\section{Introduction}

Employee silence refers to situations where employees withhold information that might be useful to the organization of which they are a part, whether intentionally or unintentionally. This can be happened if employees do not speak up to a supervisor or manager. Employees often assume that silence is the best way to solve a problem. Even in Indonesia there is a saying related to silence, that silence is gold. Employees in facing problems that occur in the company, has two alternatives to keep silence or speak. However, many employees in the company who remain silence because they think silence is the best way to avoid a problem. Employees are unaware of the consequences of silence, the silence is the starting point of a company's collapse. According to Yirik, et al. (2012) defines employee silence as not showing feelings towards a person, not sharing with others and covering the problem by behaving silence and still working as if nothing has happened. Within organizations people often have to make decisions about whether to speak up or remain silent - whether to share 
or withhold their ideas, opinions, and concerns, in many cases, they choose the safe response of silence, withholding input that could be valuable to others or thoughts that they wish they could express.

The feeling of insecurity and apprehension to share divergent views with management or co-workers had lead employees not to speak up (Milliken, Morrison, \& Hewlin, 2003). It is found on employee in secondary education Al-Hidayah Medan. In a breaktime where all the teachers were gathering together in the room and did the interaction actively. Some of them are silent while the rest of employee are busy interracting each other. This means the situation is not going to change for the better anytime soon. Employee silence does not only occur between management and employees, it also occurs during conflict among employees, work- family conflict. This silence keeps people from receiving information that may help to improve the organization.

The previous related study has been conducted before by other researcher named Umar \& Hassan (2015). This study investigates the effects that the employee intentional withholding of organisationally relevant information has on the family work domain of employees in the tertiary education institutions of the North-West geopolitical zone of Nigeria. Data was collected from 228 married employees using self-administered questionnaires. IBM SPSS Statistics and SmartPLS 3 were used to analyse the data. The findings reveal that employee silence has a significant negative relationship on work-family enrichment and no significant relationship on work-family conflict. The implications of the study and directions for future research are suggested.

Indeed, when there is a problem in the workplace, employees have two options: remain silent or speak up. Unfortunately, many employees choose to remain silent because they do not want to share information that could be interpreted as negative or threatening. Up $85 \%$ of employees in a study reported instances when they had failed to speak up about something of concern (Milliken, et al. 2003). Employees typically remain silent about conflicts with co-workers, disagreements about organizational decisions, potential weaknesses in work processes, illegal or dangerous behaviors, and individual/personal grievances. Their silence keeps management from receiving critical information that would allow their organizations to improve or address problems before they have adverse effects.

Since there are so much numerous study about employee silence, but still lack of investigating the influence on work family conflict, and there is still no investigation happen in secondary education in Medan. So this article aims to investigate the influence of work-family conflict on employee silence among emloyee in secondary education. The focus were to find out the influence of work-family conflict on employee silence among employee in secondary education Al-Hidayah Medan.

\section{Literature Review}

\section{Employe Silence}


The term employee silence is a recent construct (Morrison, 2014). According to Morrison \& Milliken's (2000), as quoted by Umar \& Hasan (2015) the construct emerged in the organisational behaviour literature with the publication in conceptual paper on organisational silence. It refers to not speak up when one has a suggestion, concern and information about a problem, or a divergent point of view that could be useful or relevant to share (Milliken et al., 2003). It also includes not writing, not being present, negative attitude, not being heard and being ignored (Deniz \& Noyan, 2013). Silence also includes "quieting, censorship,suppression, trivialization, exclusion, ghettoization and other forms of discounting" (Hazen, 2006).

Employee silence is a multifaceted concept that involves but is not limited to, lack of speech or formal voice; in fact, it may occur in the midst of sound or language. Employee silence can occur simultaneously with either sound or speech: it is not necessarily the opposite of either (Pinder \& Harlos, 2001).

\section{Work-family conflict}

Work-family conflicts are common among workers (Kelly, et al. 2011). Work-family conflict is one type of inter role conflict in which role pressures of the work and family domains involve some level of mutual incompatibility (Nielson, et al. 2001). It is a form of inter-role conflict in which the role pressures of the work and family domains are mutually incompatible in some respect. That is; participation in the work (family) role is made more difficult by virtue of participation in the family (work) role (Greenhaus \& Beutell, 1985). Recent studies validated that work-family conflict is multidimensional with effects occurring from the work domain as well as from the family domain (Nielson et al., 2001). The focus of this study is on work interference with family.

Y. Lu (2007) in Umar \& Hasan (2015) states both work and family domains have their demands and problems, and can result in either work interfering with family life, or vice versa. Studies have found relationships between work-family conflict and adverse health outcomes as well as (Stoddard \& Madsen, 2007). These studies present evidence that work-family conflict has an unfavourable effect on employees (Stoddard \& Madsen, 2007). As an individual's relationships with others can have a significant influence on the work-family conflict (Nielson, et al. 2001). The negative outcomes of silence on employee life are numerous.

\section{Hypothesis}

There is a relationship of work-family conflict on Employee silence in secondary education intitution Al-Hidayah Medan.

\section{Research Method}

This reasearch was used Quantitative research methodology (Ary, et al, 2002) where this method explains about the correlation between independent variable to dependent variable, here the independent variable $x$ (work-family conflict) and dependent varibale is y (employee silence). 
Proceedings of the $1^{\text {st }}$ Annual International Conference on Language and Literature, 18-19 April 2018, Fakultas Sastra, UISU, Medan, Indonesia.

The writers conducted the research at SMP Yayasan Al-Hidayah Medan. This school located on Jalan Starban 418 Polonia Medan. The time of the research was in November 2017.

The population of the research was the teachers at SMP Yayasan Al-Hidayah Medan, the numbers of the population were 25 teachers.

The researcher used Non-probability purposive sampling to collect the sample. The researchers were taken 10 respondents as the sample, consisting of 5 females (50\%) and 5 males (50\%).

The data was collected by using an adopted self-administered quantitative questionnaires. And the data analysis on this study was analyzed by using IBM SPSS Statistics 22 Software.

\section{Result and Discussion}

The data were analyzed by using IBM SPSS Statistics 22 Software, and the results are follows :

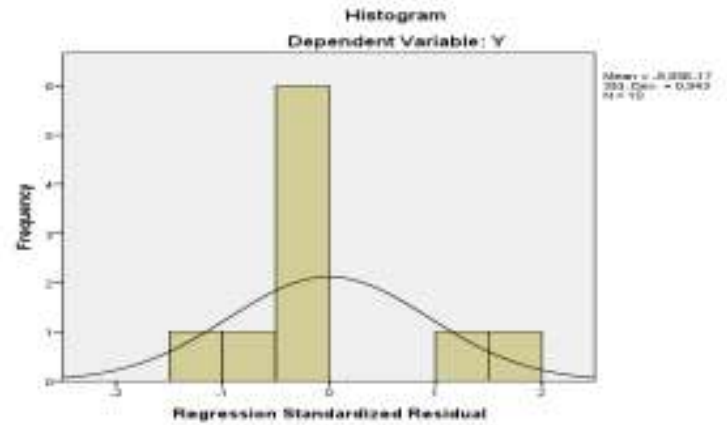

Figure 1. Normality Hystogram Test Source: Results of SPSS Data Processing (2017)

Based on the Figure 1, it can be seen that distributed variables show normal results. It can be proven by the data that is normally distributed which show by bell-shaped. While in other picture is also seen lines that follow the bell-shaped point. It means that the data is valid.

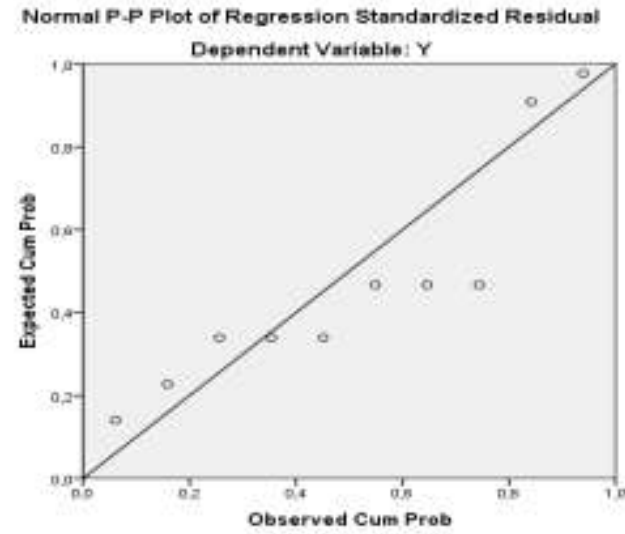

Figure 2. Plot Test Normality

Source: Results of SPSS Data Processing (2017) 
Based on the figure 2, it can be seen that variables are normally distributed. It can be shown by the data does not deviate to the left or right, while in the picture can also be seen the point that follows the data along the diagonal line. It means that the data is normally distributed.

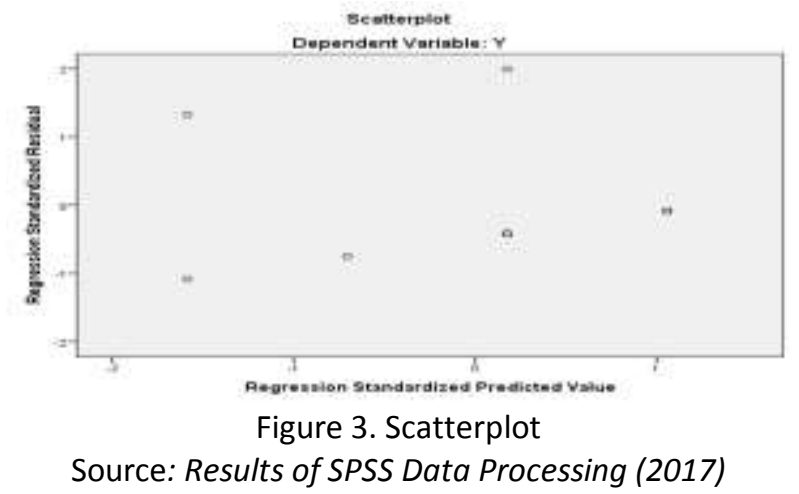

Based on the plot of data processed from the calculation of SPSS, the picture shows that the distribution of data does not accumulate at one corner, but spreads to the entire piece of data. Then, it can be concluded that there is no heteroscedasticity on the data and can be said that this research data is homogeneous.

Table 1. One-Sample Kolmogorov-Smirnov Test

\begin{tabular}{|l|l|r|}
\hline \multicolumn{2}{|l|}{$\mathrm{N}$} & Unstandardized Residual \\
\hline \multirow{2}{*}{ Normal Parameters ${ }^{\mathrm{a}, \mathrm{b}}$} & Mean & 10 \\
\cline { 2 - 3 } & Std. Deviation &, 0000000 \\
\hline \multirow{2}{*}{ Most Extreme Differences } & Absolute &, 39148015 \\
\cline { 2 - 3 } & Positive &, 335 \\
\cline { 2 - 3 } & Negative &, 335 \\
\hline Test Statistic &,- 130 \\
\hline Asymp. Sig. (2-tailed) &, 335 \\
\hline a. Test distribution is Normal. &, $002^{\mathrm{c}}$ \\
\hline b. Calculated from data. & \\
\hline c. Lilliefors Significance Correction. \\
\hline
\end{tabular}

Based on Table 1, it is seen that the value of Asymp.Sig. (2-tailed) is 0.005 . It means that the value is not above the significant value of $5 \%(0.05)$. In other words, the variable is not normally distributed.

\section{Simple Linear Regression Analysis}

To determine the influence or the relationship of independent variables $(X)$ in the form of work family conflict and the dependent variable $(\mathrm{Y})$ in the form of silence. To obtain more accurate results, the authors use the help of SPSS software program (statistic product and service solution) version 23.0 of the table coefficient. then, the resulting output is as follows:

Table 2. Coefficients ${ }^{a}$

\begin{tabular}{|c|c|c|c|c|c|c|}
\hline \multirow{2}{*}{\multicolumn{2}{|c|}{ Model }} & \multicolumn{2}{|c|}{ Unstandardized Coefficients } & Standardized Coefficients & \multirow[t]{2}{*}{$\mathrm{t}$} & \multirow[b]{3}{*}{171} \\
\hline & & B & Std. Error & Beta & & \\
\hline \multirow[t]{2}{*}{1} & (Constant) & ,724 & ,482 & & 1,504 & \\
\hline & $\mathrm{X}$ & ,862 & ,122 & ,928 & 7,071 & ,000 \\
\hline
\end{tabular}

a. Dependent Variable : $Y$ 
Based on the results of data processing as shown in table column Unstandardized Coeffisien part $B$, obtained a simple linear regression equation as follows:

$$
Y=0.724+0,862 X+e
$$

Based on the equation, it can be described as follows:

1. Constant $(a)=0,724$.It has meaning that work - family conflict $(X)$ considered constant with silence $(\mathrm{Y})$ is 0,724 .

2. Coefficient $X=0,862$. The work - family conflict variable toward silence with the regession coefficient is 0,862 . It has meaning that every progressive variable in work-family conflict by 1 unitary, so that silence will increase amount to 0,862 .

\section{Coefficient of Determination Test}

Testing coefficient of determination (R2) aims to determine how big the ability of independent variables explain the dependent variable. In SPSS output, the coefficient of determination lies in the model table and is written $R$ Square.

Table 3. The Result of Determination Identification Test Model Summary ${ }^{\text {b }}$

\begin{tabular}{|l|r|r|r|r|r|}
\hline Model & R & R Square & Adjusted R Square & $\begin{array}{c}\text { Std. Error of the } \\
\text { Estimate }\end{array}$ & Durbin-Watson \\
\hline 1 &, $928^{\mathrm{a}}$ &, 862 &, 845 &, 415 & 1,630 \\
\hline
\end{tabular}

a. Predictors: (Constant), $X$

b. Dependent Variable: $Y$

Based on the result of determination identification test in Table 3 shows that:

1 . $R=0,928$ means relation between work family conflict against silence is $92,8 \%$ which means having a close enough relationship. The larger $\mathrm{R}$ value means the relationship gets closer.

2. Adjusted $R$ Square is 0,862 means $86,2 \%$ work family conflict can affect silence. While the rest is $13.8 \%$ which is influenced by other factors that not examined by this study.

3. Standart Error of Estimatedmeans to measure the variation of the predicted value. Standart error of Estimated can also be called standard deviation. From the table above, the Standard Error of Estimated is 0.415 . The less of standard deviation means the model is getting better.

\section{Hypothesis Testing}

\section{Partial Significant Test (t-Test)}

T-test is done to test partially independent variable consisting of work family conflict $(X)$ variable has significant influence on the dependent variable $(Y)$ in the form of silence.

Decision making criteria:

$\mathrm{H}_{0}$ accepted or Harejected if $\mathrm{t}_{\text {count }} \leq \mathrm{t}_{\text {table }}$ on $\alpha=5 \%$

$\mathrm{H}_{0}$ rejected or Haaccepted if $\mathrm{t}_{\text {arithmetic }} \geq \mathrm{t}_{\text {table }}$ at $\alpha=5 \%$ 
Table 4.

Coefficients $^{a}$

\begin{tabular}{|l|l|r|r|r|r|r|}
\hline \multicolumn{2}{|l|}{ Model } & \multicolumn{2}{|c|}{ Unstandardized Coefficients } & Standardized Coefficients & \multirow{2}{*}{$\mathrm{t}$} & \\
\cline { 3 - 5 } \multicolumn{2}{l|}{} & $\mathrm{B}$ & Std. Error & Beta & \\
\hline \multirow{2}{*}{1} & (Constant) &, 724 &, 482 & & 1,504 &, 171 \\
\cline { 2 - 7 } & $\mathrm{X}$ &, 862 &, 122 &, 928 & 7,071 &, 000 \\
\hline
\end{tabular}

b. Dependent Variable $: Y$

Based on Table 4 it can be seen that:

1. The $T$ value of work family conflict variable $(X)$ is 7,071 gives a positive and significant effect of 0,000 . Hypotesis $H_{0}$ is rejected because $t_{\text {hitung }}>t_{\text {tabel }}$ $(7,071>1,859)$ which means that if the Work- Family Confllict $(X)$ varible being improved and so are Silence $(\mathrm{Y})$.

2. The constant is 0,724 . Itmeans that although the free variable is 0 , so that the performance is unchanged ie 0.724 .

Based on the result of $t$ test output, the formula of regression equation is:

$$
\begin{aligned}
& Y=a+b X+e \\
& Y=0,724+0,862 X+e
\end{aligned}
$$

\section{Conclusions}

This study aims to find the effect of Work-family Conflict on Employee Silence on Secondary Eduaction Al-Hidayah Medan Indonesia. Based on the previous study that has conducted before by (Umar \&Hassan, 2015) investigates about the effect of Work-family enrichment and Work-Family Conflict on silence which theemployee silence has a significant negative relationship on work-family enrichment and no significant relationship on work-family conflict. However in other research copes, the research found that Work-family conflict has a significant effect on employee silence. This is in line with the researcher expectations because Work-family conflicts have also been shown to induce different emotional reactions (Illies, De Pater, \& Lim, 2012), leading to an employee's difficulties to balance the demands of various role domains. This is in line with Frone, Russell, \& Barnes (Major et al., 2002) stating that work-family conflict have a close relationship with depression and somatic complaints. According to Carlson, et.al (2000) quoting from Greenhaus \& Beutell (1985), states thatwork-family conflict is the source of the stress that most individuals experience,work-family conflict is also defined as a form of conflict between roles wherepressure of the role of work and family as well as the conflicting family domainsin many ways. So therefore in this study.

The result also parades that Work-family conflict has contributed $84.5 \%$ to employee silence and $15.5 \%$ to other factors outside the Work-family conflict described in this study. Which means that the employee of Secondary Education tend to be silence mostly because of work-family conflict they have. And $15.5 \%$ are occured because other factor outside the variable Work-Family Conflict $(x)$. It could be the next further research about the causes of employee silence. 
Proceedings of the $1^{\text {st }}$ Annual International Conference on Language and Literature, 18-19 April 2018, Fakultas Sastra, UISU, Medan, Indonesia.

\section{References}

Ary, Donald., et al. (2002). Introduction to research in education. USA: Wadsworth Group

Azuar Juliandi dan Irfan. (2015). Metode Penelitian Bisnis Konsep \& Aplikasi. Diterbitkan oleh UMSU PRESS.

Brown, A. D., \& Coupland, C. (2005). Sounds of Silence: Graduate Trainees, Hegemony and Resistance. Organization Studies, 26(7), 1049-1069. Retrieved from http://core.kmi.open.ac.uk/download/pdf/9706564.pdf

Deniz, N., \& Noyan, A. (2013). The Relationship between Employee Silence and Organizational Commitment in a Private Healthcare Company. Procedia - Social and Behavioral Sciences, 99, 691-700. doi:10.1016/j.sbspro.2013.10.540

Greenhaus, J. H., \& Beutell, N. J. (1985). Sources of Conflict between Work and Family Roles. Academy of Management, 10(1), 76-88.

Greenhaus, J. H., \& Powell, G. N. (2006). When Work And Family Are Allies : A Theory Of Work-Family Enrichment. The Academy of Management Review, 31(1), 7292.

Hazen, M. A. (2006). Silences, perinatal loss, and polyphony: A post-modern perspective. Journal of Organizational Change Management, 19(2), 237-249. doi:10.1108/09534810610648933

Kelly, E. L., Moen, P., \& Tranby, E. (2011). Changing Workplaces to Reduce WorkFamily Conflict: Schedule Control in a White-Collar Organization. American Sociological Review, 76(2), 265-290. doi:10.1177/0003122411400056

Lu, J., \& Xie, X. (2013). Research on Employee Silence Behavior: A Review Based on Chinese Family Enterprise. Asian Social Science, 9(17), 47-52. doi:10.5539/ass.v9n17p47

Milliken, F. J., Morrison, E. W., \& Hewlin, P. E. (2003). An Exploratory Study of Employee Silence : Issues that Employees Don 't Communicate Upward and Why. Journal of Management Studies, 40(6), 1453-1476.

Morrison, E. W. (2014). Employee Voice and Silence. Annual Review of Organizational Psychology and Organizational Behavior, 1(1), 173-197. doi:10.1146/annurevorgpsych-031413-091328

Nielson, T. R., Carlson, D. S., \& Lankau, M. J. (2001). The Supportive Mentor as a Means of Reducing Work-Family Conflict. Journal of Vocational Behavior, 59(3), 364-381. doi:10.1006/jvbe.2001.1806

Perlow, L., \& Williams, S. (2003). Is Silence Killing Your Company ? Leadership Development : Harvard Business Review, (May).

Pinder, C. C., \& Harlos, K. P. (2001). Employee silence: Quiescence and acquiescence as responses to perceived injustice. Research in Personnel and Human Resources Management, 20(20), 331-369. doi:10.1016/50742-7301(01)20007-3

Stoddard, M., \& Madsen, S. (2007). Toward an understanding of the link between work-family enrichment and health. Institute of Behavioral and Applied Management, 2-15. Retrieved from http://works.bepress.com/ susan madsen/42/

Umar, Malami \& Zaiton, Hassan. (2015). The Influence of Employee Silence on WorkFamily Enrichment and Work Family Conflict Among Employees of Tertiary 
Educational Institutions in Nigeria. Jurnal Kemanusiaan Vol. 24 : ISSUE, 2015 ISSN : 1675-1930. Universiti Technology Malaysia

Van Dyne, L., Ang, S., \& Botero, I. C. (2003). Conceptualizing Employee Silence and Employee Voice as Multidimensional Constructs. Journal of Management Studies, 40:6 (September), 1360-1392.

Yirik, Ş. Yilmaz, Y., Demirel, O.N, Yilmaz, Y., Akgün, A, ve Hasan Kinay. (2012). Analysis of The Hotel Personnel's Conceptions of Organizational Justice, Organizational Silence, Mobbing, Organizational Commitment In Terms of Demographic Variables, 3rd International Symposium on Sustainable Development, Sarajevo. 